\title{
PENGARUH BEBAN PAJAK, MEKANISME BONUS, EXCHANGE RATE, DAN KEPEMILIKAN ASING TERHADAP INDIKASI MELAKUKAN TRANSFER PRICING
}

\author{
Rihhadatul 'Aisy Prananda \\ Program Studi Akuntansi Universitas Telkom \\ rihhaaisy@students.telkomuniversity.ac.id \\ Dedik Nur Triyanto \\ Program Studi Akuntansi Universitas Telkom \\ dediknurtriyanto@telkomuniversity.ac.id
}

\begin{abstract}
Abstrak: Pengaruh Beban Pajak, Mekanisme Bonus, Exchange Rate, dan Kepemilikan Asing Terhadap Indikasi Melakukan Transfer Pricing. Penelitian ini bertujuan untuk menguji apakah Beban Pajak, Mekanisme Bonus, Exchange Rate, dan Kepemilikan Asing berpengaruh terhadap Indikasi Melakukan Transfer Pricing pada perusahaan pertambangan yang terdaftar di Bursa Efek Indonesia selama periode 2014-2018. Teknik sampling yang digunakan dalam penelitian ini adalah nonprobability sampling dengan jenis purposive sampling sehingga diperoleh sebanyak 75 sampel dari 15 perusahaan pertambangan yang terdaftar di Bursa Efek Indonesia selama periode 2014-2018. Metode analisis yang digunakan adalah metode analisis regresi logistik dengan bantuan dari aplikasi IBM SPSS 25. Hasil dari penelitian ini menunjukkan bahwa variabel Beban Pajak dan Kepemilikan Asing secara parsial berpengaruh positif terhadap Indikasi Melakukan Transfer Pricing, sedangkan variabel Mekanisme Bonus dan Exchange Rate secara parsial tidak berpengaruh terhadap Indikasi Melakukan Transfer Pricing.
\end{abstract}

Kata kunci: Beban Pajak, Exchange Rate, Kepemilikan Asing, Mekanisme Bonus, dan Transfer Pricing

\begin{abstract}
The Effect Of Tax Expenses, Bonus Mechanism, Exchange Rate, and Foreign Ownership On Indication To Performs Transfer Pricing. This study aims to examine whether the tax expenses, bonus mechanism, exchange rate and foreign ownership affect the indications of transfer pricing on mining companies listed on the Indonesian stock exchange during the 2014-2018 period. The sampling technique used in this study is nonprobability sampling with the type of purposive sampling in order to obtain as many as 75 samples from 15 mining companies listed on the Indonesia stock exchange during the 2014-2018 period. The analytical method used is logistic regression analysis method with the help of the IBM SPSS 25 application. The results showed that both of tax expenses and foreign ownership have a positive effect on indication of transfer pricing, while bonus mechanism and exchange rate didn't have effect on indication of transfer pricing.
\end{abstract}

Keywords: Tax Expenses, Exchange Rate, Foreign Ownership, Bonus Mechanisms, and Transfer Pricing

\section{PENDAHULUAN}

Seiring dengan berkembangnya era globalisasi membuat perdagangan ekonomi menembus pasar internasional. Perusahaan lokal bertransformasi menjadi perusahaan multinasional (multinational enterprises) yang beroperasi di bawah pengendalian suatu pihak tertentu yang tidak hanya beroperasi dalam satu negara, namun dapat beroperasi di lebih dari satu negara. Mengingat operasi yang dilakukan oleh perusahaan multinasional dapat melibatkan beberapa 


\section{Nominal: Barometer Riset Akuntansi dan Manajemen \\ P-ISSN: 2303-2065 E-ISSN: 2502-5430 \\ Volume 9 No 2 (2020)}

negara yang memiliki ketentuan perpajakan berbeda, risiko perpajakan seperti upaya penghindaran pajak dapat terjadi. Penghindaran pajak dapat dilakukan dengan menggeser laba (profit shifting) melalui transaksi antar perusahaan yang memiliki hubungan istimewa, namun berada di negara yang berbeda. Perbedaan atas pengenaan tarif pajak pada setiap negara, di mana perusahaan multinasional beroperasi memicu perusahaan untuk memperkecil kewajiban pembayaran pajak dengan cara melakukan praktik transfer pricing.

Transfer pricing dapat terjadi pada perusahaan multinasional dikarenakan transfer pricing ialah kebijakan atas penetapan harga, baik harga jual maupun harga beli pada produk atau jasa tertentu yang melibatkan pihak-pihak yang memiliki hubungan istimewa atau transaksi afiliasi (Melmusi, 2016). Hubungan istimewa diatur dalam Undang-Undang No.36 Tahun 2008 Pasal 18 ayat (4) yang menjelaskan bahwasanya hubungan istimewa dapat terjadi apabila antara Wajib Pajak Badan dengan Wajib Pajak lainnya terdapat kepemilikan modal saham sebanyak 25\% atau lebih, secara langsung maupun tidak berada di bawah pengawasan yang sama, serta terdapat hubungan keluarga.

Praktik transfer pricing secara umum tidak menyalahi aturan, dan aturan perpajakan mengenai praktik-praktik transfer pricing terbilang sudah memadai mengenai bagaimana praktik transfer pricing serta perlakuan perpajakannya. Hal yang disayangkan dalam praktik transfer pricing ini masih banyak digunakan oleh pihak yang ingin menghindari membayar pungutan pajak yang besar, dalam hal ini perusahaan multinasional mentransfer laba perusahaan ke negara lain yang menetapkan tarif pajak lebih rendah. Tarif pajak yang semakin tinggi ditetapkan oleh suatu negara kemungkinan besar akan memunculkan motif perusahaan multinasional untuk menjalankan praktik transfer pricing ini.

Bagi negara yang menetapkan tarif pajak yang relatif tinggi akan semakin rendah penerimaan negara yang diperoleh karena para pelaku praktik transfer pricing cenderung melakukan pemindahan laba ke negara yang menetapkan tarif yang lebih rendah. Terlihat jelas dampak negatif atas penerimaan negara akibat praktik transfer pricing, namun tidak jarang pemerintah kalah saat mengajukan banding ke pengadilan pajak. Kurangnya sumber daya manusia yang memahami mengenai transfer pricing dan minimnya pemeriksa pajak yang memahami mengenai transfer pricing dalam Direktorat Jenderal Pajak menyebabkan pemeriksaan terhadap perusahaan multinasional yang terindikasi melakukan praktik transfer pricing juga sangat terbatas. Sehingga perusahaan multinasional dapat 


\section{Nominal: Barometer Riset Akuntansi dan Manajemen \\ P-ISSN: 2303-2065 E-ISSN: 2502-5430 \\ Volume 9 No 2 (2020)}

memanfaatkan celah-celah yang ada untuk melakukan praktik transfer pricing ini.

Beban pajak yang terlalu besar yang harus dibayarkan kepada negara dapat mengakibatkan perusahaan memutuskan untuk melakukan praktik transfer pricing agar dapat menekan dan atau meminimalkan besarnya beban pajak yang harus dibayarkan (Fitri, 2018). Penelitian mengenai beban pajak dalam indikasi melakukan transfer pricing telah dilakukan, di antaranya oleh Tiwa dkk. (2017) dan Saraswati \& Sujana (2017) yang menemukan bahwa pajak berpengaruh signifikan secara positif terhadap transfer pricing. Lain pula dengan hasil penelitian yang telah dilakukan Mispiyanti (2015) dan Melmusi (2016) yang menemukan bahwa pajak tidak berpengaruh signifikan terhadap transfer pricing.

Faktor lain yang dapat memengaruhi keputusan perusahaan dalam menentukan apakah melakukan atau tidak melakukan praktik transfer pricing adalah mekanisme bonus. Mekanisme dasar pemberian bonus berdasarkan pada besarnya laba yang diperoleh, suatu hal yang masuk akal apabila direksi berupaya mengatur sebagaimana mestinya laba dapat dimaksimalkan demi mendapatkan bonus walaupun itu harus sedikit di manipulatif dengan memanfaatkan transfer pricing (Hartati, Desmiyawati, \& Julita, 2015). Hasil penelitian oleh Melmusi (2016) menyimpulkan bahwa mekanisme bonus berpengaruh signifikan secara positif terhadap transfer pricing, akan tetapi bertentangan dari hasil penelitian yang ditemukan Saraswati \& Sujana (2017) serta Ayshinta dkk. (2019) yang menemukan bahwa mekanisme bonus tidak berpengaruh terhadap transfer pricing.

Motif lainnya yang memungkinkan dapat memengaruhi perusahaan dalam menetapkan kebijakan transfer pricing adalah exchange rate atau nilai tukar. Nilai tukar yang terus menerus berfluktuasi akan memengaruhi besaran harga produk atau jasa yang dihasilkan perusahaan, maka keputusan transfer pricing lah yang dijadikan pilihan oleh manajemen agar jumlah kas yang tersedia dapat digunakan untuk melakukan transaksi (Ayshinta dkk., 2019). Hasil penelitian mengenai pengaruh exchange rate terhadap transfer pricing yang dilakukan Ayshinta dkk. (2019) menemukan bahwa exchange rate berpengaruh signifikan secara positif terhadap transfer pricing, namun tidak sejalan dengan Pratiwi (2018) yang menyimpulkan bahwa exchange rate tidak berpengaruh terhadap transfer pricing.

Dalam PSAK No.15 pemegang saham pengendali merupakan entitas dengan kepemilikan saham 20\% atau lebih, baik kepemilikan langsung ataupun tidak langsung terhadap entitas lain sehingga dapat memberikan pengaruh yang besar dalam mengendalikan entitas (Melmusi, 2016). 
Nominal: Barometer Riset Akuntansi dan Manajemen

P-ISSN: 2303-2065 E-ISSN: 2502-5430

Volume 9 No 2 (2020)

Semakin besarnya pemegang saham KAJIAN LITERATUR

pengendali asing memiliki proporsi Teori Keagenan (Agency Theory)

kepemilikan saham, maka pemegang saham pengendali asing mempunyai kendali atas ketetapan penting perusahaan yang lebih besar pula dibandingkan dengan pemegang saham non pengendali. Hasil penelitian dari Kusumasari dkk. (2018) dan Refgia (2017) membuktikan bahwa kepemilikan asing berpengaruh terhadap transfer pricing, namun tidak sejalan dengan Tiwa dkk. (2017) dan Cristea \& Nguyen (2016) yang membuktikan bahwasanya kepemilikan asing tidak berpengaruh signifikan terhadap transfer pricing.

Fenomena masalah yang terjadi terkait dengan transfer pricing serta adanya ketidakkonsistenan pada hasil penelitian terdahulu membuat penulis tertarik untuk mengangkat kembali beban pajak, mekanisme bonus, exchange rate, dan kepemilikan asing sebagai variabel independen dan indikasi melakukan transfer pricing sebagai variabel dependen. Berdasarkan latar belakang yang telah dijelaskan, maka penulis tertarik untuk mereplikasi variabel terkait menggunakan judul "Pengaruh Beban Pajak, Mekanisme Bonus, Exchange Rate dan Kepemilikan Asing Terhadap Indikasi Melakukan Transfer Pricing".

Teori keagenan dibangun sebagai suatu upaya agar dapat menemukan jalan keluar untuk memecahkan suatu masalah yang timbul apabila terdapat ketidaklengkapan informasi ketika melakukan sebuah perjanjian atau kontrak. Kontrak antara prinsipal (pemberi kerja) dengan agen (penerima pemerintah) lah kontrak yang dimaksud. Teori keagenan memperkirakan agen akan mempunyai keunggulan dibandingkan dengan prinsipal dalam kecepatan dalam menerima informasi, yang dapat menimbulkan adanya asimetri informasi atau ketimpangan informasi yang diterima pihak tertentu (Gudono, 2017:142143).

\section{Teori Akuntansi Positif}

Teori Akuntansi Positif menurut Watts \& Zimmerman yaitu teori akuntansi memiliki tujuan untuk menjelaskan (to explain) dan untuk memprediksi (to predict) praktik akuntansi yang dijalankan. Maksud untuk menjelaskan di sini yaitu mempersiapkan alasan atas praktik akuntansi yang dijalankan untuk bisa diobservasi, kemudian maksud memprediksi di sini yaitu bahwa teori akuntansi dapat memperkirakan fenomena yang tidak mampu terobservasi sebelumnya (Wardiyah, 2016:8). 
Pendapat lain mengenai teori akuntansi positif bahwa teori akuntansi positif menyediakan seperangkat prinsip yang luas agar dapat menjelaskan, yang berarti memberi jawaban terhadap praktik akuntansi yang berlaku serta dapat memprediksi fenomena yang terjadi (Hery, 2017:106107). Hipotesis mengenai mekanisme pemberian bonus merupakan contoh penerapan dari teori akuntansi positif ini, menjelaskan bahwa manajemen yang remunerasinya berdasarkan bonus akan berupaya memaksimalkan bonus yang akan diperoleh dengan memakai metode akuntansi yang dapat menaikkan laba dan pada akhirnya dapat memperbesar pemberian bonus.

\section{Transfer Pricing}

Transfer pricing atau penentuan harga transfer merupakan suatu kebijakan yang digunakan dalam menentukan besarnya harga transfer atas suatu transaksi yang melibatkan penjualan atau pembelian atas barang, jasa, intangible assets, maupun transaksi finansial lainnya yang dilakukan perusahaan (Herawaty \& Anne, 2019).

Istilah transfer pricing sering dikaitkan dengan sesuatu hal yang tidak baik atau bermakna "peyoratif". Menurut Plasschaert, secara peyoratif transfer pricing merupakan suatu rekayasa harga secara sistematis dengan tujuan mengurangi laba artifisial agar terlihat "rugi" sehingga dapat menghindari pembayaran pajak di suatu negara (Pohan, 2018). Abuse of transfer pricing merupakan contoh dari hal yang bermakna peyoratif, sebab istilah abuse of transfer pricing sendiri memiliki arti pemindahalihan pendapatan. Perusahaan dalam negara bertarif pajak tinggi akan memindahalihkan pendapatannya ke perusahaan yang memiliki hubungan istimewa di luar negara beroperasi dan bertarif pajak lebih rendah. Hal ini dilakukan dengan tujuan untuk mengurangi beban pajak yang harus dibayarkan (Doly, 2016).

Transaksi antara satu pihak dengan pihak afiliasinya (pihak yang memiliki hubungan istimewa) cenderung tidak mencerminkan harga pasar yang wajar, maka dari itu Direktorat Jenderal Pajak (DJP) berwenang untuk menguji penerapan prinsip kewajaran dan kelaziman usaha. Prinsip kewajaran dan kelaziman usaha tercermin dalam transaksi yang dilakukan dengan pihak-pihak independen. Oleh karena itu, transaksi kepada pihak independen menjadi tolak ukur kewajaran atas transaksi kepada pihak berafiliasi (Pohan, 2018).

Direktur Jenderal Pajak (DJP) juga memiliki wewenang untuk menetapkan harga transaksi antara pihak-pihak yang memiliki hubungan afiliasi atau istimewa dalam suatu periode tertentu serta memantau bagaimana pelaksanaannya. Maka dari itu pemerintah menetapkan peraturan mengenai 
pelaksanaan kesepakatan harga transfer (advance pricing agreement). Advance Pricing Agreement (APA) merupakan perjanjian antara pihak DJP dengan Wajib Pajak bersangkutan mengenai sistem penentuan harga transfer yang sesuai untuk satu set transaksi yang diterbitkan selama periode tertentu. APA diadakan dengan tujuan agar dapat mengurangi perusahaan multinasional menyalahgunakan praktik transfer pricing ini (Pohan, 2018).

\section{Pengaruh Beban Pajak terhadap Indikasi Melakukan Transfer Pricing}

Praktik transfer pricing masih menjadi salah satu alternatif penghindaran pajak perusahaan agar dapat meminimalkan besarnya beban pajak yang harus dibayarkan kepada negara dengan memanipulasi laporan keuangan dan merekayasa penetapan harga transfer antar perusahaan dalam satu grup yang sama yang memiliki hubungan istimewa. Yuniasih berpendapat bahwa semakin besar beban pajak yang wajib dibayarkan, semakin besar pula praktik transfer pricing akan diterapkan oleh perusahaan demi meringankan beban pajak yang harus dibayarkan tersebut (Rosa, Andini, \& Raharjo, 2017).

$\mathrm{H}_{1}$ : Beban pajak berpengaruh positif terhadap indikasi melakukan transfer pricing.

\section{Pengaruh Mekanisme Bonus terhadap Indikasi Melakukan Transfer Pricing}

Mekanisme pemberian bonus merupakan sebuah apresiasi yang diberikan oleh pemilik perusahaan kepada manajer dan direksi apabila target laba yang sudah di tetapkan dapat terpenuhi. Mekanisme pemberian bonus ini akan mengakibatkan manajer melakukan tindak manipulatif atas data laporan keuangan agar terlihat bahwa laba telah tercapai dan nantinya manajer lah yang akan menikmati pemberian bonus tersebut (Lilik Purwanti, 2010). Dalam melakukan penilaian kinerja atas kinerja manajer dan juga direksi, pemilik perusahaan mempertimbangkan pencapaian yang telah diraih oleh manajer dan direksi. Penilaian atas pencapaian laba secara keseluruhan membuat manajer dan direksi akan berupaya penuh dalam memaksimalkan laba perusahaan dengan menerapkan praktik transfer pricing (Hartati et al., 2015).

$\mathrm{H}_{2}$ : Mekanisme bonus berpengaruh positif terhadap indikasi melakukan transfer pricing.

\section{Pengaruh Exchange Rate terhadap}

\section{Indikasi Melakukan Transfer Pricing}

Exchange rate merupakan nilai tukar mata uang suatu negara dengan mata uang negara lainnya yang dapat digunakan sebagai alat pembayaran pada masa kini atau di masa yang akan datang. Exchange rate dapat 


\section{Nominal: Barometer Riset Akuntansi dan Manajemen \\ P-ISSN: 2303-2065 E-ISSN: 2502-5430 \\ Volume 9 No 2 (2020)}

memengaruhi neraca perdagangan di suatu negara akibat perbedaan antara nilai ekspor dan impor yang diperoleh suatu negara (Cahyadi \& Noviari, 2018). Nilai tukar yang terus menerus berfluktuasi akan memengaruhi besaran harga produk atau jasa yang dihasilkan perusahaan, maka keputusan transfer pricing lah yang dijadikan pilihan oleh manajemen agar jumlah kas yang tersedia dapat digunakan untuk melakukan transaksi (Ayshinta dkk., 2019).

$\mathrm{H}_{3}$ : Exchange rate berpengaruh positif terhadap indikasi melakukan transfer pricing.

\section{Pengaruh Kepemilikan Asing terhadap}

\section{Indikasi Melakukan Transfer Pricing}

Dalam PSAK No.15 pemegang saham pengendali merupakan entitas dengan kepemilikan saham 20\% atau lebih, baik kepemilikan langsung ataupun tidak langsung terhadap entitas lain sehingga dapat memberikan pengaruh yang besar dalam mengendalikan entitas (Melmusi, 2016). Ketika pemegang saham pengendali didominasi oleh pemegang saham asing, maka pemegang saham asing mempunyai pengaruh yang semakin besar dalam menetapkan berbagai keputusan yang akan digunakan oleh perusahaan, termasuk keputusan dalam menentukan besarnya penentuan harga yang dapat diimplementasikan dalam praktik transfer pricing.

$\mathrm{H}_{4}$ : Kepemilikan asing berpengaruh positif terhadap indikasi melakukan transfer pricing.

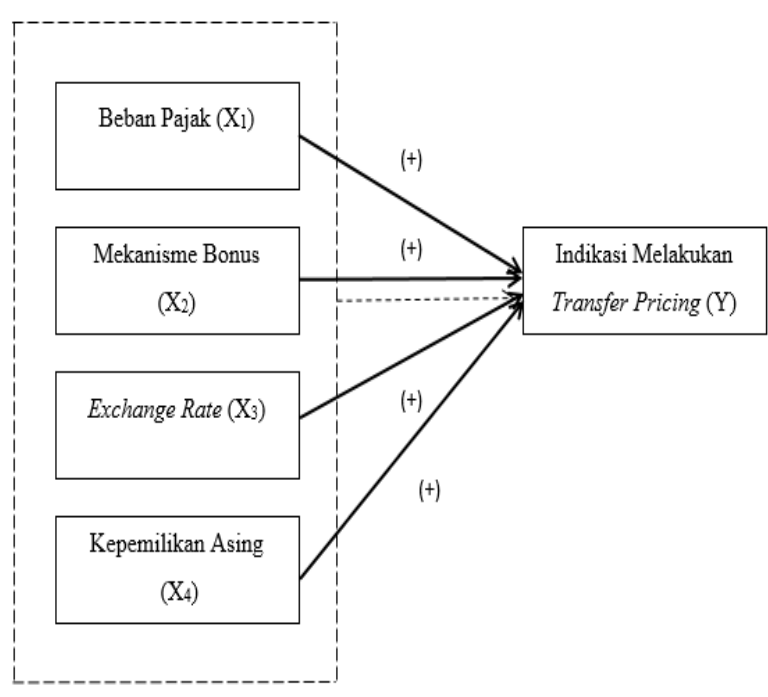

Gambar 1: Kerangka Pemikiran

\section{METODE PENELITIAN}

Penelitian ini bersifat kausal, penelitian kausal sebagaimana didefinisikan oleh (Indrawati, 2015:117) merupakan penelitian yang dilakukan bilamana peneliti ingin menggambarkan penyebab (causes) dari suatu masalah. Dalam hal ini, tujuan penulis melakukan penelitian kausal yaitu agar mampu menyatakan bahwa variabel independen yang terdiri atas beban pajak, mekanisme bonus, exchange rate dan kepemilikan asing dapat memengaruhi variabel dependen yaitu indikasi melakukan transfer pricing baik penyebab positif maupun negatif. 


\section{Populasi dan Sampel}

Sektor Pertambangan yang terdaftar di Bursa Efek Indonesia (BEI) periode 20142018 menjadi populasi yang digunakan dalam penelitian ini, terdiri sebanyak 41 perusahaan yang terdapat pada sektor pertambangan.

Nonprobability sampling merupakan teknik sampling yang digunakan pada penelitian ini, sampel diperoleh dari populasi dan dipilih secara sengaja berdasarkan pertimbangan tertentu, sehingga tidak seluruh populasi mempunyai kesempatan yang sama untuk menjadi sampel (Purwanto \& Sulistyastuti, 2017:47). Kriteria pengambilan sampel yang ditetapkan dalam penelitian ini meliputi:

Tabel 1. Kriteria Pemilihan Sampel

\begin{tabular}{|c|c|c|}
\hline No. & Keterangan & Jumlah \\
\hline 1 & $\begin{array}{l}\text { Perusahaan pertambangan } \\
\text { yang terdaftar di Bursa Efek } \\
\text { Indonesia (BEI) pada tahun } \\
\text { 2014-2018 }\end{array}$ & 41 \\
\hline 2 & $\begin{array}{l}\text { Perusahaan pertambangan } \\
\text { yang tidak konsisten } \\
\text { menerbitkan laporan tahunan } \\
\text { dan laporan keuangan yang } \\
\text { telah di audit secara lengkap } \\
\text { selama tahun 2014-2018 }\end{array}$ & (11) \\
\hline 3 & $\begin{array}{l}\text { Perusahaan pertambangan } \\
\text { yang mengalami rugi selama } \\
\text { tahun 2014-2018 }\end{array}$ & (15) \\
\hline \multicolumn{2}{|c|}{$\begin{array}{l}\text { Jumlah perusahaan sampel } \\
\text { penelitian }\end{array}$} & 15 \\
\hline \multicolumn{2}{|c|}{ Jumlah data penelitian $(15 \times 5)$} & 75 \\
\hline
\end{tabular}

tahun dari tahun 2014 hingga tahun 2018, diperoleh 75 sampel dari 15 perusahaan sampel yang dapat digunakan pada penelitian ini.

\section{Metode Pengumpulan Data}

Data sekunder digunakan pada penelitian ini, di mana data dikumpulkan dengan teknik-teknik sebagai berikut:

1. Studi Kepustakaan, dengan memperoleh data baik dari buku-buku ilmiah, jurnal dari penelitian sebelumnya, serta referensi lainnya yang berkaitan dengan pembahasan penelitian yang dilakukan.

2. Dokumentasi, dilakukan dengan cara mengumpulkan laporan tahunan dan laporan keuangan perusahaan pertambangan yang terdaftar di Bursa Efek Indonesia (BEI) periode 2014-2018 melalui website resmi BEI dan melalui website resmi perusahaan terkait.

\section{Operasionalisasi Variabel}

\section{a. Indikasi Melakukan Transfer Pricing}

Variabel dependen yang digunakan dalam penelitian ini yaitu indikasi melakukan transfer pricing. Diukur menggunakan pendekatan dikotonomi, di mana dilihat dari posisi penjualan kepada pihak berafiliasi atau pihak yang memiliki hubungan istimewa. Apabila perusahaan melakukan transaksi yang berhubungan dengan pihak istimewa, maka diberi nilai satu (1) dan diberi nilai nol (0) apabila tidak melakukan transaksi yang berhubungan dengan pihak istimewa (Cahyadi \& Noviari, 2018). 
Nominal: Barometer Riset Akuntansi dan Manajemen

P-ISSN: 2303-2065 E-ISSN: 2502-5430

Volume 9 No 2 (2020)

\section{b. Beban Pajak}

Beban pajak di ukur menggunakan proksi Effective Tax Rate (ETR). ETR merupakan persentase besaran pajak yang ditanggung oleh perusahaan, dihitung dengan mengurangi beban pajak (tax expense) dengan beban pajak tangguhan (differed tax expense) lalu dibagi dengan laba kena pajak (Saraswati \& Sujana, 2017).

ETR

$$
=\frac{\text { Tax expense }- \text { Differed tax expense }}{\text { Laba Kena Pajak }}
$$

\section{c. Mekanisme Bonus}

Mekanisme bonus dalam penelitian ini di proksikan menggunakan Indeks Trend Laba Bersih (ITRENDLB), berdasarkan besarnya pencapaian laba bersih tahun $\mathrm{t}$ terhadap laba bersih tahun t-1 (Fitri, 2018).

$$
\text { ITRENDLB }=\frac{\text { Laba bersih tahun } \mathrm{t}}{\text { Laba bersih tahun } \mathrm{t}-1}
$$

\section{d. Exchange Rate}

Variabel exchange rate dihitung menggunakan laba rugi selisih kurs dibandingkan dengan laba rugi sebelum pajak (Cahyadi \& Noviari, 2018).

$$
\text { Exchange Rate }=\frac{\text { Laba rugi selisih kurs }}{\text { Laba rugi sebelum pajak }}
$$

\section{e. Kepemilikan Asing}

Variabel kepemilikan asing di ukur dengan membagi jumlah kepemilikan saham asing dengan total saham yang beredar. Jumlah kepemilikan saham asing yang dimaksud yaitu besarnya komposisi saham yang dimiliki penanam modal asing pada akhir periode, sedangkan total saham yang beredar dihitung dengan cara menjumlahkan keseluruhan saham yang dimiliki perusahaan yang diterbitkan pada akhir periode (Kusumasari dkk., 2018).

Kepemilikan Asing = Jumlah kepemilikan saham asing Total saham beredar

\section{Metode Analisis Data}

Teknik analisis data dalam penelitian ini menggunakan statistik deskriptif serta menggunakan metode analisis regresi logistik dengan bantuan aplikasi IBM SPSS 25 .

\section{HASIL PENELITIAN DAN \\ PEMBAHASAN}

\section{Analisis Statistik Deskriptif}

Tabel 2. Hasil Pengujian Statistik Deskriptif

\begin{tabular}{lccccc}
\hline Variabel & N & Min & Max & Mean & $\begin{array}{c}\text { Std } \\
\text { Dev }\end{array}$ \\
\hline $\mathrm{BP}$ & 75 & 0.09 & 19.96 & 0.74 & 2.28 \\
$\mathrm{MB}$ & 75 & -0.98 & 25.16 & 2.18 & 3.98 \\
$\mathrm{ER}$ & 75 & -7.62 & 1.33 & -0.16 & 0.98 \\
$\mathrm{KA}$ & 75 & 0.00 & 0.97 & 0.36 & 0.30 \\
$\mathrm{TP}$ & 75 & 0.00 & 1.00 & 0.69 & 0.46 \\
Valid N & 75 & & & \\
\hline \multicolumn{5}{c}{ Sumber: Output SPSS 25 }
\end{tabular}

Berdasarkan hasil pada tabel hasil pengujian statistik deskriptif, dapat diketahui bahwa variabel dependen yaitu indikasi melakukan transfer pricing yang diukur menggunakan variabel dummy memiliki nilai rata-rata sebesar 0,69 dan standar deviasi 


\section{Nominal: Barometer Riset Akuntansi dan Manajemen}

P-ISSN: 2303-2065 E-ISSN: 2502-5430

Volume 9 No 2 (2020)

sebesar 0,46. Hal ini menunjukkan bahwa variabel indikasi melakukan transfer pricing tidak bervariasi atau merupakan data berkelompok. Nilai minimum dan nilai maksimum variabel transfer pricing ini masing-masing sebesar nol (0) dan satu (1).

Variabel beban pajak yang diukur menggunakan ETR (Effective Tax Rate) menghasilkan nilai rata-rata sebesar 0,74 dan standar deviasi sebesar 2,28. Menunjukkan bahwa variabel beban pajak bervariasi atau tidak berkelompok. Nilai minimum dan nilai maksimum keduanya dimiliki oleh PT Darma Henwa Tbk dengan nilai masingmasing sebesar 0,09 dan 19,96.

Variabel mekanisme bonus yang diukur menggunakan ITRENDLB (Indeks Trend Laba Bersih) menghasilkan nilai rata-rata sebesar 2,18 dan standar deviasi sebesar 3,98. Hal ini menunjukkan bahwa data variabel mekanisme bonus bervariasi atau tidak berkelompok. Nilai minimum dimiliki oleh PT J Resources Asia Pasifik Tbk (2014) sebesar -0,98, dan nilai maksimum dimiliki oleh PT Surya Esa Perkasa Tbk (2018) sebesar 25,16.

Variabel exchange rate menghasilkan nilai rata-rata sebesar $-0,16$ dan standar deviasi sebesar 0,98 . Hal ini menunjukkan bahwa data variabel exchange rate bervariasi atau tidak berkelompok. Nilai minimum dimiliki oleh PT Citatah Tbk (2014) sebesar
-7,62, dan nilai maksimum dimiliki oleh PT Darma Henwa Tbk (2016) sebesar 1,33.

$$
\text { Variabel kepemilikan asing }
$$
menghasilkan nilai rata-rata sebesar 0,36 dan standar deviasi sebesar 0,30. Hal ini menunjukkan bahwa data variabel kepemilikan asing tidak bervariasi atau merupakan data berkelompok. Nilai minimum dimiliki oleh PT J Resources Asia Pasifik Tbk (2014) sebesar nol (0), dan nilai maksimum dimiliki oleh PT Golden Energy Mines Tbk (2015) sebesar 0,97.

\section{Menilai Kelayakan Model Regresi}

Tabel 3. Hosmer and Lemeshow Test

\begin{tabular}{cccc}
\hline Step & Chi-square & df & Sig. \\
\hline 1 & 6.730 & 7 & .457 \\
\hline \multicolumn{2}{c}{ Sumber: } & Output SPSS & 25 \\
(2020)
\end{tabular}

Berdasarkan tabel 3 dapat dilihat bahwa hasil uji dari hosmer and lemeshow test memiliki hasil chi-square sebesar 6,730 dengan signifikasi sebesar 0,457 yang menunjukkan bahwa nilai signifikansi lebih besar dari 0,05 maka hipotesis diterima atau tidak dapat ditolak, sehingga model dapat dikatakan fit.

Menilai Model Fit (Overall Fit Test Model) Tabel 4. Overall Model Fit

\begin{tabular}{cc}
\hline \multicolumn{2}{c}{ Overall Model Fit } \\
\hline-2 LogL Block & Bernilai 92.461 \\
Number $=0$ & \\
-2LogL Block & Bernilai 66.693 \\
Number $=1$ & \\
\hline \multicolumn{2}{l}{ Sumber: Output SPSS $25(2020)$}
\end{tabular}


Berdasarkan Tabel 4 dapat dilihat bahwa nilai awal -2Log likelihood (Block Number $=$ 0) sebesar 92,461 dan nilai -2Log likelihood (Block Number $=1)$ sebesar 66.693. Hal ini menunjukkan bahwa nilai -2Log likelihood (Block Number $=1)$ lebih kecil dibandingkan dengan nilai -2Log likelihood (Block Number $=0)$ dengan penurunan sebesar 25,768, sehingga dapat disimpulkan bahwa model fit dengan data ,dan terbukti bahwa variabel beban pajak, mekanisme bonus, exchange rate, dan kepemilikan asing secara signifikan dapat memperbaiki model fit.

\section{Koefisien Determinasi}

Tabel 5. Koefisien Determinasi

\begin{tabular}{cccc}
\hline \multicolumn{4}{c}{ Model Summary } \\
\hline Step & -2 Log & Cox \& & Nagelkerke \\
likelihood & $\begin{array}{c}\text { Snell } R \\
\text { Square }\end{array}$ & R Square \\
\hline 1 & $66.693^{\mathrm{a}}$ & .291 & .410 \\
\hline
\end{tabular}

Tabel 5 menunjukkan hasil pengujian dari Nagelkerke's $R$ Square sebesar 0,410 atau sebesar $41 \%$ yang memiliki arti bahwa variabel beban pajak, mekanisme bonus, exchange rate, dan kepemilikan asing mampu menjelaskan variasi dari indikasi melakukan praktik transfer pricing sebesar $41 \%$ dan selebihnya sebesar $59 \%$ dipengaruhi oleh variabel lain yang tidak digunakan dalam penelitian ini. Menurut (Sugiyono, 2018:284), koefisien determinasi sebesar $41 \%$ termasuk kategori sedang.

\section{Uji Signifikansi Simultan (Uji F)}

Tabel 6. Omnibus Test of Model Coeffisients

\begin{tabular}{ccccc}
\hline & & $\begin{array}{c}\text { Chi- } \\
\text { square }\end{array}$ & df & Sig. \\
\hline Step & Step & 25.768 & 4 & .000 \\
1 & Block & 25.768 & 4 & .000 \\
& Model & 25.768 & 4 & .000 \\
\hline
\end{tabular}

Sumber: Output SPSS 25 (2020)

Pada Tabel 6 dapat dilihat bahwa ChiSquare sebesar 25,678 dengan degree of freedom (df) sebesar 4. Tingkat signifikansi yang dihasilkan sebesar 0,000 (p-value< 0.05), dengan demikian secara simultan variabel beban pajak, mekanisme bonus, exchange rate, dan kepemilikan asing berpengaruh terhadap variabel indikasi melakukan transfer pricing.

\section{Uji Signifikansi Parsial (Uji T)}

Tabel 7. Variable in the Equation

B S.E. Wald df Sig. $\operatorname{Exp}(B)$

\begin{tabular}{|c|c|c|c|c|c|c|}
\hline$\left(\mathrm{X}_{1}\right)$ & 3.64 & 1.56 & 5.42 & 1 & 0.02 & 38.04 \\
\hline$\left(\mathrm{X}_{2}\right)$ & -0.11 & 0.08 & 1.85 & 1 & 0.17 & 0.89 \\
\hline$\left(\mathrm{X}_{3}\right)$ & 1.23 & 0.77 & 2.57 & 1 & 0.11 & 3.42 \\
\hline$\left(\mathrm{X}_{4}\right)$ & 4.77 & 1.60 & 8.88 & 1 & 0.00 & 118 \\
\hline Constant & -1.72 & 0.84 & 4.20 & 1 & 0.04 & 0.18 \\
\hline
\end{tabular}

\section{Model Persamaan Logistik}

$$
\begin{aligned}
& \operatorname{Ln} \frac{p}{(1-p)}=-1,722+3,639 \mathrm{X}_{1}-0,112 \mathrm{X}_{2}+ \\
& 1,228 \mathrm{X}_{3}+4,771 \mathrm{X}_{4}+\mathrm{e}
\end{aligned}
$$

Keterangan:

Ln: $\log$ of odds

P: Probabilitas melakukan transfer pricing

$\mathrm{X}_{1}$ : Beban Pajak

$\mathrm{X}_{2}$ : Mekanisme Bonus

$\mathrm{X}_{3}$ : Exchange Rate 
Nominal: Barometer Riset Akuntansi dan Manajemen

P-ISSN: 2303-2065 E-ISSN: 2502-5430

Volume 9 No 2 (2020)

$\mathrm{X}_{4}$ : Kepemilikan Asing

e: Error Term

\section{Pembahasan}

\section{Pengaruh Beban Pajak terhadap Indikasi Melakukan Transfer Pricing}

Berdasarkan Tabel 7, nilai signifikansi beban pajak lebih kecil dari 0,05 yaitu 0,02 dengan nilai koefisien regresi bernilai positif sebesar 3,64. Sehingga dapat disimpulkan bahwa beban pajak berpengaruh signifikan secara positif terhadap indikasi melakukan transfer pricing pada perusahaan pertambangan yang terdaftar di Bursa Efek Indonesia (BEI) periode 2014-2018. Hasil ini menunjukkan bahwa besarnya beban pajak dapat memengaruhi perusahaan untuk menerapkan praktik transfer pricing agar dapat menekan beban pajak yang harus dibayarkan kepada negara. Hasil penelitian ini sejalan dengan penelitian yang dilakukan oleh Tiwa dkk. (2017) dan Saraswati \& Sujana (2017) yang menyimpulkan bahwa pajak berpengaruh positif terhadap transfer pricing.

\section{Pengaruh Mekanisme Bonus terhadap Indikasi Melakukan Transfer Pricing}

Berdasarkan Tabel 7, nilai signifikansi mekanisme bonus lebih besar dari 0,05 yaitu 0,17 dengan nilai koefisien regresi bernilai negatif sebesar -0,11. Sehingga dapat disimpulkan bahwa mekanisme bonus tidak berpengaruh terhadap indikasi melakukan transfer pricing pada perusahaan pertambangan yang terdaftar di Bursa Efek Indonesia (BEI) periode 2014-2018. Hasil ini menunjukkan bahwa besarnya bonus yang diberikan tidak berdasarkan laba yang diperoleh secara keseluruhan. Belum tentu laba yang besar akan menjadikan alasan pihak manajemen menerima bonus yang besar pula sehingga harus menerapkan praktik transfer pricing. Hasil penelitian ini sejalan dengan penelitian yang dilakukan oleh Saraswati \& Sujana (2017) serta Ayshinta dkk., (2019) yang menyimpulkan bahwa mekanisme bonus tidak berpengaruh terhadap transfer pricing.

\section{Pengaruh Exchange Rate terhadap Indikasi Melakukan Transfer Pricing}

Berdasarkan Tabel 7, nilai signifikansi exchange rate lebih besar dari 0,05 yaitu 0,11 dengan nilai koefisien regresi bernilai positif sebesar 1,23. Sehingga dapat disimpulkan bahwa exchange rate tidak berpengaruh terhadap indikasi melakukan transfer pricing pada perusahaan pertambangan yang terdaftar di Bursa Efek Indonesia (BEI) periode 2014-2018. Hasil ini menunjukkan bahwa meningkat atau tidaknya nilai tukar terhadap rupiah tidak memengaruhi keputusan perusahaan dalam menetapkan kebijakan transfer pricing atau tidak. Hasil penelitian ini sejalan dengan penelitian yang dilakukan oleh Marfuah dkk. (2014) dan 
Pratiwi (2018) yang menunjukkan bahwa exchange rate tidak berpengaruh terhadap transfer pricing.

\section{Pengaruh Kepemilikan Asing terhadap Indikasi Melakukan Transfer Pricing}

Berdasarkan Tabel 7, nilai signifikansi kepemilikan asing lebih kecil dari 0,05 yaitu 0,00 dengan nilai koefisien regresi bernilai positif sebesar 4,77. Sehingga dapat disimpulkan bahwa kepemilikan asing berpengaruh secara positif terhadap indikasi melakukan transfer pricing pada perusahaan pertambangan yang terdaftar di Bursa Efek Indonesia (BEI) periode 2014-2018. Hasil ini menunjukkan bahwa semakin besar kepemilikan asing dalam suatu perusahaan maka semakin besar pula perusahaan akan melakukan kebijakan transfer pricing. Hasil penelitian ini sejalan dengan penelitian yang dilakukan oleh Refgia (2017) yang menyimpulkan bahwa kepemilikan asing berpengaruh terhadap transfer pricing.

\section{SIMPULAN DAN SARAN}

\section{Simpulan}

Berdasarkan hasil analisis statistik deskriptif dan pengujian menggunakan model regresi logistik, diperoleh kesimpulan penelitian sebagai berikut:

1. Beban pajak berpengaruh signifikan secara positif terhadap indikasi melakukan transfer pricing pada perusahaan pertambangan yang terdaftar di Bursa Efek Indonesia (BEI) periode 2014-2018

2. Mekanisme bonus tidak berpengaruh terhadap indikasi melakukan transfer pricing pada perusahaan pertambangan yang terdaftar di Bursa Efek Indonesia (BEI) periode 2014-2018.

3. Exchange rate tidak berpengaruh terhadap indikasi melakukan transfer pricing pada perusahaan pertambangan yang terdaftar di Bursa Efek Indonesia (BEI) periode 2014-2018.

4. Kepemilikan asing berpengaruh signifikan secara positif terhadap indikasi melakukan transfer pricing pada perusahaan pertambangan yang terdaftar di Bursa Efek Indonesia (BEI) periode 2014-2018.

\section{Saran}

Penelitian ini hanya menggunakan perusahaan pada sektor pertambangan sehingga hasil tidak dapat menggeneralisasi jenis sektor lain karena perbedaan kondisi industri. Peneliti selanjutnya diharapkan dapat menggunakan jenis sektor lain dengan menambahkan variabel independen lainnya yang tidak digunakan dalam penelitian ini seperti intangible asset, debt covenant, tunneling incentive, firm size, dan proksi lainnya yang mungkin dapat memengaruhi indikasi melakukan transfer pricing. 


\section{DAFTAR PUSTAKA}

Ayshinta, P. J., Agustin, H., \& Afriyenti, M. (2019). Pengaruh Pajak, Tunneling Incentive, Dan Mekanisme Bonus Terhadap Keputusan Perusahaan Melakukan Transfer Pricing. JEA.

Cahyadi, A. S., \& Noviari, N. (2018). Pengaruh Pajak, Exchange Rate, Profitabilitas, dan Leverage Pada Keputusan Melakukan Transfer Pricing. E-Jurnal Akuntansi. https://doi.org/10.24843/EJA.2018.v24. i02.p23

Cristea, A. D., \& Nguyen, D. X. (2016). Transfer pricing by multinational firms: New evidence from foreign firm ownerships. American Economic Journal: Economic Policy. https://doi.org/10.1257/pol.20130407

Doly, T. (2016). Transfer Pricing Dalam Negeri. Retrieved from http://www.nusahati.com/2016/05/trans fer-pricing-dalam-negeri/

Fitri, A. (2018). Pengaruh Beban Pajak, Intangible Assets, Profitabilitas, Tunneling Incentive Dan Mekanisme Bonus Terhadap Transfer Pricing (Studi Empiris Pada Perusahaan Manufaktur Yang Listing di BEI Periode 20142016). JOM Fekon, 1(1), 1-14.

Gudono. (2017). Teori Organisasi (Edisi 4). Yogyakarta: ANDI.

Hartati, W., Desmiyawati, \& Julita. (2015). Tax Minimization, Tunneling Incentive dan Mekanisme Bonus terhadap Keputusan Transfer Pricing Seluruh Perusahaan yang Listing di Bursa Efek Indonesia. Jurnal SNA.

Herawaty, V., \& Anne, A. (2019). Pengaruh Tarif Pajak Penghasilan, Mekanisme Bonus, Dan Tunneling Incentives Terhadap Pergeseran Laba Dalam Melakukan Transfer Pricing Dengan Good Corporate Governance Sebagai
Variabel Moderasi. Jurnal Akuntansi

Trisakti.

https://doi.org/10.25105/jat.v4i2.4836

Hery. (2017). Teori Akuntansi : Pendekatan Konsep dan Analisis (D. S., Ed.). Jakarta: PT Grasindo.

Indrawati. (2015). Metode Penelitian Manajemen dan Bisnis Konvergensi Teknologi Komunikasi dan Informasi (Di. Sumayyah, Ed.). Bandung: PT Refika Aditama.

Kusumasari, R. D., Fadilah, S., \& Sukarmanto, E. (2018). Pengaruh Pajak , Kepemilikan Asing dan Ukuran Perusahaan terhadap Transfer Pricing ( Studi Empiris pada Perusahaan Manufaktur yang Terdaftar di Bursa Efek Indonesia Periode 2012-2016 ). Prosiding Akuntansi.

Lilik Purwanti. (2010). Kecakapan Managerial, Skema Bonus, Managemen Laba, dan Kinerja Perusahaan. Jurnal Aplikasi Manajemen.

Melmusi, Z. (2016). Pengaruh Pajak , Mekanisme Bonus, Terhadap Transfer Pricing Pada Perusahaan Yang Tergabung Dalam Jakarta Islamic Index. Jurnal EKOBISTEK.

Mispiyanti. (2015). Pengaruh Pajak, Tunneling Incentive dan Mekanisme Bonus terhadap Keputusan Transfer Pricing. Jurnal Akuntansi \& Investasi.

Pohan, C. A. (2018). Pedoman Lengkap Pajak Internasional. Jakarta: PT Gramedia Pustaka Utama.

Pratiwi, B. (2018). Pengaruh Pajak, Exchange Rate, Tunneling Incentive, Dan Leverage Terhadap Transfer Pricing. Jurnal Ekonomi Dan Bisnis. https://doi.org/10.30659/ekobis.19.3.90 $-103$

Purwanto, E. A., \& Sulistyastuti, D. R. (2017). Metode Penelitian Kuantitatif 
Untuk Adminitrasi Publik dan MasalahMasalah Sosial (Edisi Kedu). Yogyakarta: Penerbit Gava Media.

Refgia, T. (2017). Pengaruh Pajak, Mekanisme Bonus, Ukuran Perusahaan, Kepemilikan Asing dan Tunneling Incentive terhadap Transfer Pricing. JOM Fekon.

Rosa, R., Andini, R., \& Raharjo, K. (2017). Pengaruh Pajak, Tunneling Incentive, Mekanisme Bonus, Debt Covenant dan Good Corporate Governance (GCG) Terhadap Transaksi Transfer Pricing. Jurnal Universitas Pandanaran Semarang.

Saraswati, G. A. R. S., \& Sujana, I. K. (2017). Pengaruh Pajak, Mekanisme Bonus, dan Tunneling Incentive Pada Indikasi Melakukan Transfer Pricing. EJurnal Akuntansi Universitas Udayana.

Sugiyono. (2018). Metode Penelitian Kuantitatif (Setiyawami, Ed.). Bandung: Alfabeta, CV.

Wardiyah, M. L. (2016). Akuntansi Keuangan Menengah. Bandung: CV Pustaka Setia. 